\title{
Plant Stress Analysis Technology Deployment
}

\author{
Topical Report \\ January 1998
}

\author{
By: \\ M. A. Ebadian
}

Work Performed Under Contract No.: DE-FG21-95EW55094

For

U.S. Department of Energy

Office of Fossil Energy

Federal Energy Technology Center

P.O. Box 880

Morgantown, West Virginia 26507-0880

RECEIVED

OCT 201998

O.STI.

\section{By}

Florida International University

Hemispheric Center for Environmental Technology (HCET)

Center for Engineering \& Applied Sciences

10555 West Flagler Street

EAS-2100

Miami, Florida 33174 


\section{Disclaimer}

This report was prepared as an account of work sponsored by an agency of the United States Government. Neither the United States Government nor any agency thereof, nor any of their employees, makes any warranty, express or implied, or assumes any legal liability or responsibility for the accuracy, completeness, or usefulness of any information, apparatus, product, or process disclosed, or represents that its use would not infringe privately owed rights. Reference herein to any specific commercial product, process, or service by trade name, trademark, manufacturer, or otherwise does not necessarily constitute or imply its endorsement, recommendation, or favoring by the United States Government or any agency thereof. The views and opinions of authors expressed herein do not necessarily state or reflect those of the United States Government or any agency thereof. 


\title{
DISCLAIMER
}

\author{
Portions of this document may be illegible \\ in electronic image products. Images are \\ produced from the best available original \\ document.
}


1.0 INTRODUCTION ... 1

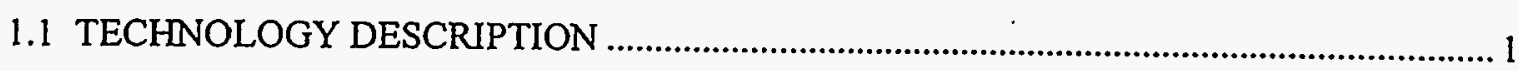

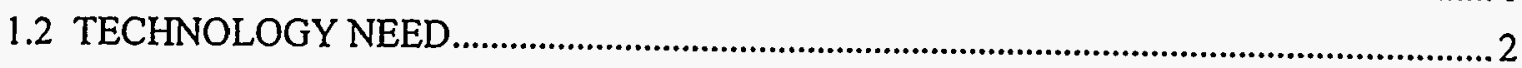

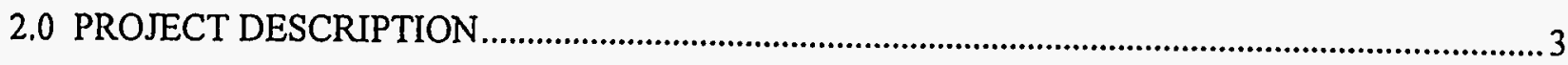

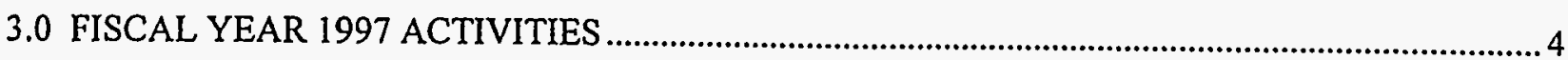

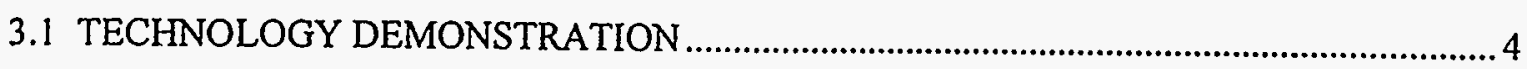

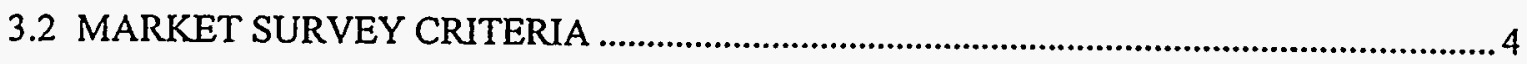

3.3 U.S. DEPARTMENT OF AGRICULTURE (USDA) CONTACT …................................... 4

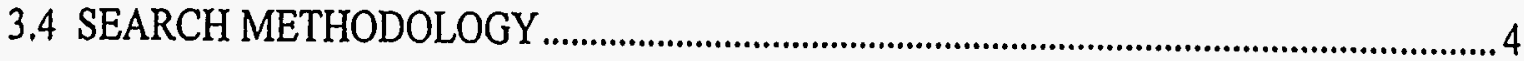

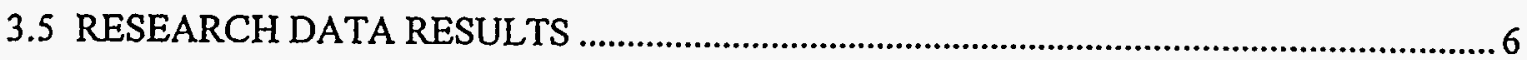

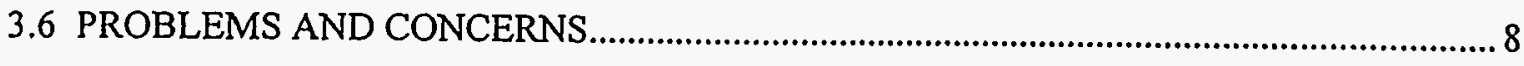

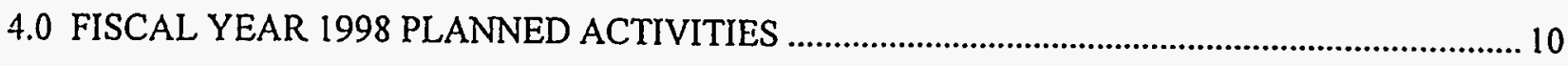

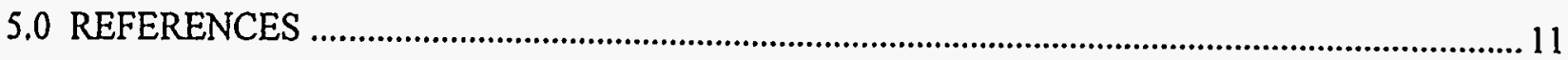




\subsection{INTRODUCTION}

Fluorescence techniques have the ability to detect signatures that are not observable using traditional remote sensing methods. The high spatial resolution of intensified charged-coupled device (CCD) cameras and the time-resolved phosphorescence emission characteristics of certain compounds allow digital recording of their presence and scope. The real-time image processing of the data into a false color composite on a gray-scale background allows the operator to distinguish the signatures of interest. As a result, mitigation efforts can be focused on specific areas, thus expediting the survey and lowering overall costs. While this is a well-understood process in the detection of uranium oxides, the use of fluorescence for monitoring vegetation is and will remain an area of research for years to come. There are a variety of known plant responses related to pests, and so forth. A clear understanding of needs and their economic significance will provide direction for future efforts.

Monitoring vegetation is an active area of laser-induced fluorescence imaging (LIFI) research. The Hemispheric Center for Environmental Technology (HCET) at Florida International University (FIU) is assisting in the transfer of the LIFI technology to the agricultural private sector through a market survey. The market survey will help identify the key eco-agricultural issues of the nations that could benefit from the use of sensor technologies developed by the Office of Science and Technology (OST). The principal region of interest is the Western Hemisphere, particularly, the rapidly growing countries of Latin America and the Caribbean.

The analysis of needs will assure that the focus of present and future research will center on economically important issues facing both hemispheres. The application of the technology will be useful to the agriculture industry for airborne crop analysis as well as in the detection and characterization of contaminated sites by monitoring vegetation. LIFI airborne and closeproximity systems will be evaluated as stand-alone technologies and additions to existing sensor technologies that have been used to monitor crops in the field and in storage.

\subsection{TECHNOLOGY DESCRIPTION}

Fluorescence is the prompt luminescence of a material caused by an external stimulus, such as a laser or a filtered conventional light source. LIFI is an optical technique that exploits the detection of fluorescent compounds irradiated with laser light and the images that result from recording spatial data. Common compounds that fluoresce include organics such as chlorophyll in plants and hydrocarbon fuels. When uranium is excited by an ultra-violet (UV) laser, its peak fluorescence is persistent (phosphorescent), lasting much longer than the laser pulse. This delay, coupled with the detection of specific spectral bands, enables the detection of the presence of uranium.

LIFI is being developed by Special Technologies Laboratory (STL). The work is sponsored by the Characterization, Monitoring, and Sensor Technologies Crosscutting Program (CMST-CP) of the OST. The LIFI project encompasses a variety of techniques to exploit LIFI in several environmental applications, including aerial remote sensing and hand-held portable survey tools for detecting uranium on surfaces and subsurface contaminants via vegetation stress. The project 
has resulted in the development of hardware, software, and analysis methods for ground-based and airborne LIFI systems.

The current LIFI configurations include UV and visible laser sources $(355 \mathrm{~nm}$ and $532 \mathrm{~nm}$ wavelength), intensified $\mathrm{CCD}$ cameras, and real-time image processing for instantaneous viewing. In the close-proximity systems (e.g., the uranium survey tool), video images are stored digitally for future display and analysis. The airborne system stores a large "cube" of imagery in multiple colors using custom interface and a disk array.

\subsection{TECHNOLOGY NEED}

Two markets appear to be in need of a technology for remote monitoring, the identification of contaminated regions, and the monitoring of the progress of remediation work and the health of vegetation. One is the environmental restoration market, which includes government agencies such as DOE, who are responsible for land stewardship and the public health at DOE facilities. The other is the agricultural market, which is concerned with crop protection against disease and other stresses that impact crop yield, eventual shelf-life, and profitability. Expanding the number of users will make the technology more affordable to the remediation customer.

Laser-induced fluorescence is a technique that is deployed as a number of technologies. These technologies are defined by the sensing requirements such as standoff distance, signal sensitivity, and the spectral and spatial characteristics of the signature. The primary consideration determining the system's size and complexity is the size of the area to be monitored.

The LIFI technologies developed at STL are divided into two classes: (1) the airborne/long-range LIFI systems and (2) the close-proximity technologies such as the uranium survey tool. While many agricultural uses are envisioned for the existing technologies, it is more likely that a different configuration will prove to be cost competitive for commercial use. The LIFI technologies at STL are constantly updated for new applications. The needs statement will be used to determine the appropriate technologies. A description of two technologies is given below.

An airborne survey tool for fluorescence signature detection promises area coverage of sites that are geographically dispersed or have poor access. LIFI applications include environmental assessment and monitoring for the detection of uranium during decontamination and decommissioning (D\&D) activities; the detection of polyaromatic (organic) compounds (PAHs) and vegetation stress as an indicator of subsurface contamination; and the early detection of plant disease and general plant degradation. Close-proximity LIFI technologies promise highresolution coverage at distances that permit the use of much smaller systems. These include systems that are used for hot spot detection or process monitoring.

For the technology to be competitive in a commercial marketplace such as the agricultural market, it must be made available through private enterprise. To ensure a successful commercialization plan, a market survey of agricultural needs must be made. The market survey serves to identify the LIFI technology that is most appropriate for a particular need and the signatures that will ultimately be exploited (e.g., skin damage of fruit). Most importantly, the survey will define the extent of need and the cost/benefit of the technology implementation that is required to demonstrate commercial viability. 


\subsection{PROJECT DESCRIPTION}

The purpose of this project is for HCET to assist in the deployment of the LIFI technology in the agricultural private sector through a market survey. The market survey will help determine whether an agricultural commercial market demand exists for the LIFI technology and enable HCET personnel to assess the potential deployment opportunities that exist for the LIFI technology in Latin America.

The market survey will help identify the key eco-agricultural concerns of the nations that could benefit from the use of sensor technologies developed by the OST. The analysis of needs will ensure that present and future research will center on economically important issues in Latin America. The technology will be useful to the agriculture industry for airborne crop analysis as well as for the detection and characterization of contaminated sites by monitoring vegetation. LIFI airborne and close-proximity systems will be evaluated as stand-alone technologies and as additions to existing sensor technologies that have been used to monitor crops in the field and in storage. 


\subsection{FISCAL YEAR 1997 ACTIVITIES}

\subsection{TECHNOLOGY DEMONSTRATION}

HCET personnel traveled to EPCOT at Walt Disney World to observe LIFI at work. STL's scientists, in conjunction with EPCOT researchers, deployed the LIFI equipment to run experiments in EPCOT's greenhouse. HCET personnel spent two days observing the manner in which plant stress was measured through fluorescence reflectance from chlorophyll.

\subsection{MARKET SURVEY CRITERIA}

HCET personnel established the criteria for conducting the agricultural market survey. The primary regional focus for LIFI-pertinent research and analysis is Latin America. Argentina, Chile, Brazil, Mexico, and Colombia were selected as the main targets for the survey based on their economy's growth and strength, agricultural dominance, market share, exporting activity, financial resources, and favorable economic environments.

\subsection{U.S. DEPARTMENT OF AGRICULTURE (USDA) CONTACT}

A librarian at the USDA National Library provided extensive information on the major crops raised in the selected Latin American countries. The librarian also provided information about the USDA's Remote Sensing \& Modeling Laboratory, which is conducting research in the remote sensing field and has published several research reports that are an important source of information for this project.

\subsection{SEARCH METHODOLOGY}

Valid data are, perhaps, the most crucial aspect of the market study. It was determined that the primary agricultural concerns of each country must be analyzed. To obtain a complete and accurate analysis of each country's agrarian concerns, specific crop data were necessary. It was determined that the primary six crops for each respective country would be researched. In addition, the information would also include crop production in metric tons (MT) and primary exports, in MT and the dollar value of exports.

Since valid and verifiable data are necessary, HCET personnel used the libraries at FIU and the USDA. HCET personnel were also referred to various government Websites on the Internet since they provide the most recent information. Consequently, most of the researched data were obtained through government-regulated and government-operated Websites. Federal government Websites were selected to ensure optimal validity and accuracy of the retrieved records. 
The Websites used most frequently include:

- The Food and Agriculture Organization (FAO) of the United Nations Homepage (http://www.fao.org)

- Central Intelligence Agency (CIA) World Factbook Homepage (http://www.odci.gov/cia/publications/nsolo/wfb-all.htm)

- U.S. Department of Agriculture Homepage (http://www.fas.usda.gov)

- The International Trade Library Homepage, formerly known as the National Trade Data Bank (http://www.domino.stat-usa.gov)

- U.S. Department of Commerce International Trade Administration (ITA) Homepage (http://www.ita.doc.gov)

- U.S. Department of Commerce ITA-Latin America Homepage (http://www.ita.doc.gov/olac/\#regions)

The United Nations Website provided an extremely useful directory of departments and phone numbers, as well as very helpful Internet links. The most important and beneficial resource that the United Nations Website provided is the United Nations FAO Homepage link. Among the many links the FAO Webpage provides is the FAO Production Yearbook. The FAOSTAT Database yielded each individual country's production in metric tons, as well as each individual country's exports in metric tons and in a monetary value $(\$ 1000)$. This database has a wide scope and provides a large selection of data and material. The data provided is both verifiable and current.

The CIA's Homepage yielded another extremely important link. The CIA Website links allowed HCET personnel to find the CIA World Factbook, which supplied essential information about each country. Another Website that was heavily used is the International Trade Library, which provided the Background Notes from the Secretary of State, Bureau of Public Affairs. These sites allowed HCET personnel to further research and analyze each country's social, economic, and political environments.

The U.S. Department of Commerce ITA provided a wealth of information concerning each country's trade and commerce activities. ITA's Latin America section also yielded specific data concerning crop production and exports. Information concerning particular regional and site-specific trade information was extremely helpful.

Also, several state and local government Websites were used in the search. These included:

- University of Texas Latin America Network Information Center Website (http://www.lanic.utexas.edu)

- FIU Latin American and Caribbean Center Homepage (http://www.fiu.edu/ lacc)

Other Internet Websites that are mainly privately owned and run by International organizations were used and cross referenced to evaluate the agricultural problems and concerns for the Latin 
American regions. Once the information was obtained, additional Internet Websites were used and researched. The most often-used agricultural Websites included:

- Agrinet International Homepage (http://www.agrinetinternational.com), which provides agricultural and general information for farmers, agents, property purchasers, and the agricultural community

- AgriLinks Homepage (http://www.agrilinks.com/related.html\#agorg), which provides useful links to the international agricultural community

- AgriBusiness Assistant Homepage (http://www.trace sc.com/agri), which provides links to Latin America in general and Mexico in particular

Once the information was compiled, each Latin American country's general consulates and embassies in the United States were contacted by HCET personnel. The consulate and embassy personnel provided additional insight and guidance and assisted in the verification of the results. In addition, the United Nations Headquarters in New York City was contacted by HCET personnel. U.N. personnel referred HCET researchers to the FAO offices in New York and Washington, D.C.

After researching all possible sources, raw data were tabulated and correlated. A table containing raw data for each country was generated reflecting major crops and exports. Also, problems and concerns were identified and analyzed. HCET personnel found that some problems are particular to a country and others pertain to the entire region.

\subsection{RESEARCH DATA RESULTS}

The major crops and exports for each selected country were researched, compiled, and tabulated in the following table:

\begin{tabular}{|c|c|c|c|c|c|}
\hline \multirow[t]{2}{*}{ Country } & \multirow[t]{2}{*}{$\begin{array}{l}\text { Primary } \\
\text { Crops* }\end{array}$} & \multirow[t]{2}{*}{$\begin{array}{r}\text { Production } \\
\text { (metric tons) }\end{array}$} & \multicolumn{3}{|l|}{$\begin{array}{l}\text { Primary } \\
\text { Exports* }\end{array}$} \\
\hline & & & Crop & $\begin{array}{r}\text { Dollar Value } \\
(\$ 1000)\end{array}$ & $\begin{array}{r}\text { Quantity } \\
\text { (metric tons) }\end{array}$ \\
\hline \multirow[t]{6}{*}{ Argentina } & Sugar Cane & $17,400,000$ & Bovine Meat & $1,071,549$ & 442,008 \\
\hline & Soybeans & $12,134,000$ & Wheat & $1,005,372$ & $6,913,286$ \\
\hline & Maize & $11,404,000$ & Oilseeds & 875,058 & $3,595,488$ \\
\hline & Wheat & $9,185,000$ & Maize & 682,289 & $6,000,873$ \\
\hline & Sunflower Seed & $5,604,000$ & Soybeans & 535,966 & $2,549,840$ \\
\hline & Grapes & $2,854,814$ & Sunflower Seed & 208,269 & 845,095 \\
\hline
\end{tabular}




\begin{tabular}{|c|c|c|c|c|c|}
\hline \multirow[t]{6}{*}{ Brazil } & Maize & $36,274,580$ & Coffee, Green & $1,969,869$ & 721,305 \\
\hline & Soybeans & $25,651,270$ & Sugar, Total & $1,919,459$ & $6,364,370$ \\
\hline & Cassava & $25,315,600$ & $\begin{array}{l}\text { Orange juice } \\
\text { Conc. }\end{array}$ & $1,105,393$ & 961,193 \\
\hline & Oranges & $19,613,100$ & Soybeans & 770,426 & $3,492,525$ \\
\hline & Rice, Paddy & $11,225,990$ & Bovine Meat & 492,800 & 182,757 \\
\hline & Bananas & $5,679,780$ & Oranges & 29,092 & 114,061 \\
\hline \multirow[t]{6}{*}{ Chile } & Sugar Beets & $3,744,000$ & Grapes & 345,343 & 442,818 \\
\hline & Milk, Total & $1,883,000$ & Apples & 197,176 & 432,522 \\
\hline & Grapes & $1,526,860$ & Kiwi Fruit & 65,586 & 111,210 \\
\hline & Wheat & $1,383,861$ & Pears & 58,475 & 146,841 \\
\hline & Tomatoes & $1,264,244$ & $\begin{array}{l}\text { Peaches/ } \\
\text { Nectarines }\end{array}$ & 60,806 & 84,343 \\
\hline & Maize & 942,223 & $\begin{array}{l}\text { Apple Juice } \\
\text { Conc. }\end{array}$ & 52,386 & 30,939 \\
\hline \multirow[t]{6}{*}{ Colombia } & Sugar Cane & $32,000,000$ & Coffee, Green & $1,837,243$ & 558,745 \\
\hline & Plantains & $2,783,465$ & Bananas & 431,239 & $1,360,278$ \\
\hline & Bananas & $2,100,000$ & Tobacco & 22,925 & 11,821 \\
\hline & Rice, Paddy & $1,742,547$ & Cotton Lint & 12,776 & 5,372 \\
\hline & Coffee, Green & $1,043,266$ & Berries & 3,266 & 235 \\
\hline & Maize & $1,034,043$ & Beef and Veal & 3,034 & 1,176 \\
\hline \multirow[t]{6}{*}{ Mexico } & Sugar Cane & $42,561,800$ & Coffee, Green & 766,410 & 187,171 \\
\hline & Maize & $16,187,000$ & Tomatoes & 585,608 & 717,289 \\
\hline & Oranges & $3,571,541$ & Cotton Lint & 169,926 & 93,424 \\
\hline & Wheat & $3,468,220$ & Mangoes & 104,793 & 131,721 \\
\hline & Bananas & $2,032,652$ & Sugar, Total & 83,662 & 482,995 \\
\hline & Tomatoes & $1,935,470$ & Wheat & 72,068 & 431,775 \\
\hline
\end{tabular}

*The information in this table was obtained from the United Nations' Food and Agricultural Organization's Database. 
The following information was obtained from the U.S. Department of State, Office of Public Affairs Background Notes and the CIA's World Factbook.

\section{Argentina}

Major export products: Meat, wheat, corn, oilseeds, hides, wool

Agriculture: (7\% of Gross Domestic Product (GDP), about $60 \%$ of exports by value)

GDP; $\$ 292$ billion

\section{Brazil}

Major export products: Coffee, soybeans, sugarcane, cocoa, rice, beef

Agriculture: (11\% of GDP)

GDP: $\$ 456$ billion

\section{Chile}

Major export products: Wheat, potatoes, corn, sugar beets, onions, beans

Agriculture: ( $8 \%$ of GDP)

GDP: $\$ 46.2$ billion

\section{Colombia}

Major export products: Coffee, bananas, flowers, sugar

Agriculture: (21\% of GDP)

GDP: $\$ 50$ billion

\section{Mexico}

Major export products: Coffee, cotton

Agriculture: (5.8\% of GDP)

GDP: $\$ 370$ billion

\subsection{PROBLEMS AND CONCERNS}

Crop losses in Latin America have several primary and identifiable causes. Crop distress and the destruction of harvests stem from many different sources. Most crop loss is due to pests, including, but not limited to, insects, mites, fungi, bacteria, viruses, and weeds. Integrated Pest Management is a very important aspect of Latin American agriculture. Usually, when plant distress is discovered, an epidemiological culprit is suspected. The next course of action is 
usually overuse of pesticides and chemicals. Even if another plant or weed is suspected of causing crop damage or loss, pesticides and chemicals are once again overused and abused.

Research indicates that pesticide and chemical overuse is the main cause for concern for all of Latin America. Pesticides, fertilizers, and chemicals are routinely overworked into soils and their respective environments. Sometimes, small farmers incorrectly administer lethal combinations of chemicals, thereby contaminating both soil and water sources. In addition, contaminated soils and water are consumed by cattle, which are also very important sources of food and revenue for several of the selected Latin American countries.

For example, irrigated soil in Argentina is much more susceptible to any sort of epidemiological or invasive plant attacks. Also, soil and water contamination from pesticides and fertilizers are shown to have adversely affected crop production. The main focus of Argentinean research is pest and weed control, and beef cattle herd management and animal health.

In Brazil, problems caused by whiteflies (Homoptera:Aleyrodidae) have occurred for 100 years. Consequently, whiteflies have become known as 'the Pest of the Century', and have been unsuccessfully treated with pesticides and chemicals. Overuse of pesticides has led to environmental pollution and successive crop distress.

A recent article from Chile exhibits the dangers of pesticide overuse. It was shown that airplanes spraying insecticides, which are used to kill persistent moths, harmed the human fruit pickers as well as the crops. It was also shown that the pesticides being used were the most inexpensive, which are usually also the most toxic and harmful.

Research indicates that deadly overuse of fertilizers to maximize and intensify crop production, has lead to severe ramifications throughout Latin America. This practice endangers farmers' health through soil and water contamination. Soil and water contamination also leads to crop distress and production loss. Furthermore, increased pesticide usage creates a pesticide resistance in the particular regional pests and insects. The overuse of chemicals also destroys the natural enemies of these targeted pests and insects.

Since pest resistance is increased and the natural enemies of the pests also proliferate, there is an increased amount of pest activity within these particular regions. Chemicals also modify soil structure and water composition, which in turn are damaging and distressing crops and harvests. 


\subsection{FISCAL YEAR 1998 PLANNED ACTIVITIES}

During Fiscal Year 1998, this project will assess the needs and potential range of applications of the LIFI technology within the DOE complex. Specifically, HCET personnel will research DOE's Subsurface Contaminants Focus Area and verify those needs with the needs of site users. HCET personnel will survey several DOE sites to compile a list of subsurface contaminants that are currently of interest and concern to those sites. This list will be delivered to STL.

\section{Task I. Research DOE needs}

HCET personnel will research and gather information on potential characterization and monitoring needs by contacting the Subsurface Contaminants Focus Area and surveying several DOE sites. Also, STL personnel will generate an information package reflecting potential LIFI applications.

\section{Task II. Review and prioritize DOE needs}

HCET and STL personnel will review and prioritize DOE needs based on potential benefits such as cost savings, visibility, etc. The list of needs will be used to direct LIFI research efforts to address the high priority needs. STL will conduct research and development activities to determine LIFI's ability to help the sites meet those characterization and monitoring needs.

\section{Task III. Contact DOE sites to propose potential LIFI application}

HCET personnel will assist in contacting DOE sites for demonstration and ultimate deployment of LIFI. STL will test LIFI at the sites to prove performance.

\section{Task IV. Coordinate with DOE sites for LIFI ultimate deployment}

DOE, HCET and STL will collaborate in the demonstration and ultimate deployment of LIFI at the appropriate sites.

Note: HCET and STL personnel, with the assistance of the DOE project facilitator, are working together to agree on the final scope. 


\subsection{REFERENCES}

\begin{tabular}{|c|c|c|}
\hline WEBSITE ADDRESS & $\begin{array}{c}\text { NAME OF. } \\
\text { ORGANIZATION }\end{array}$ & DESCRIPTION \\
\hline http://www.odci.gov/cia/ & $\begin{array}{l}\text { The Central Intelligence } \\
\text { Agency }\end{array}$ & CIA homepage \\
\hline $\begin{array}{l}\text { http://www.odci.gov/cia/ } \\
\text { publications/nsolo/wfb-all.html }\end{array}$ & CIA World Factbook & World Factbook homepage \\
\hline http://www.stat-usa.gov/ & STAT-USA/INTERNET & $\begin{array}{l}\text { A service of the U.S. Dept. of } \\
\text { Commerce (original) }\end{array}$ \\
\hline $\begin{array}{l}\text { http://www.domino.stat- } \\
\text { usa.gov/ }\end{array}$ & STAT-USA/INTERNET & New redesigned Website \\
\hline $\begin{array}{l}\text { http://www.domino.stat- } \\
\text { usa.gov/ntdb.html }\end{array}$ & $\begin{array}{l}\text { The International Trade } \\
\text { Library }\end{array}$ & $\begin{array}{l}\text { Formerly known as National } \\
\text { Trade Data Bank (NTDB) }\end{array}$ \\
\hline http://www.usda.gov/ & $\begin{array}{l}\text { The United States } \\
\text { Department of Agriculture }\end{array}$ & \\
\hline http://www.fas.usda.gov/ & $\begin{array}{l}\text { The United States } \\
\text { Department of Agriculture } \\
\text { Foreign Agricultural Service }\end{array}$ & \\
\hline http://www.fao.org/ & $\begin{array}{l}\text { The Food and Agriculture } \\
\text { Organization of the United } \\
\text { Nations }\end{array}$ & \\
\hline $\begin{array}{l}\text { http://www.fao.org/WAICENT/ } \\
\text { Agricul.html }\end{array}$ & $\begin{array}{l}\text { FAOSTAT Agriculture } \\
\text { Database }\end{array}$ & $\begin{array}{l}\text { Primary Source for Raw } \\
\text { Agricultural Data }\end{array}$ \\
\hline http://www.un.org/ & United Nations & United Nations homepage \\
\hline http://www.un.org/aroundworld/ & UN Around the World & \\
\hline http://www.ita.doc.gov/ & $\begin{array}{l}\text { U.S. Department of } \\
\text { Commerce International } \\
\text { Trade Administration }\end{array}$ & \\
\hline $\begin{array}{l}\text { http://www.ita.doc.gov/ } \\
\text { olac/\#regions }\end{array}$ & $\begin{array}{l}\text { U.S. Department of } \\
\text { Commerce International } \\
\text { Trade Administration -Latin } \\
\text { America }\end{array}$ & Latin America Information \\
\hline
\end{tabular}




\begin{tabular}{|c|c|c|}
\hline http://www.lanic.utexas.edu/ & $\begin{array}{l}\text { Latin American Network } \\
\text { Information Center }\end{array}$ & $\begin{array}{l}\text { Latin America General } \\
\text { Information }\end{array}$ \\
\hline $\begin{array}{l}\text { http://www.agrinetinternat } \\
\text { ional.com }\end{array}$ & Agrinet International & \\
\hline http://www.txinfinit.com & Sustainable Sources & Ecological Ideas \\
\hline http://www.agronomy.org & $\begin{array}{l}\text { American Society of } \\
\text { Agronomy }\end{array}$ & \\
\hline http://www.crops.org & $\begin{array}{l}\text { Crop Science Society of } \\
\text { America }\end{array}$ & \\
\hline http://www.soils.org & $\begin{array}{l}\text { Soil Science Society of } \\
\text { America }\end{array}$ & \\
\hline $\begin{array}{l}\text { http://www.ciat.cgiar.org/ } \\
\text { frames/tex_main.htm }\end{array}$ & $\begin{array}{l}\text { International Center for } \\
\text { Tropical Agriculture }\end{array}$ & $\begin{array}{l}\text { Integrated Pest Management } \\
\text { (IPM) }\end{array}$ \\
\hline http://www.fertilizer.org & $\begin{array}{l}\text { International Fertilizer } \\
\text { Industry Organization } \\
\text { Association }\end{array}$ & Fertilizer Information \\
\hline http://www.agrilinks.com/ & Agrilinks & Agricultural Links \\
\hline $\begin{array}{l}\text { http://www.trace- } \\
\text { sc.com/agri.htm }\end{array}$ & Agri Business Assistant & Mexican Web Links \\
\hline
\end{tabular}

